\title{
THE FRENCH DECLARATION OF THE RIGHTS OF MAN AND CITIZEN AND THE AMERICAN CONSTITUTIONAL DEVELOPMENT*
}

The thorough examination of the influence of the French Declaration of the Rights of Man and Citizen on constitutions has long awaited proper implementation. The importance of the French act has never been questioned but its multi-sided impact has not been satisfactorily evaluated. With respect to the American Constitution, this problem merits a specially comprehensive study. Although the American and French politics at the end of the $18^{\text {th }}$ century were carefully examined, the links between the constitutional developments of both countries has never been researched exhaustively. The reasons seem to be threefold. First, with exception of the American Constitution, the French Declaration preceded all other written constitutions in the world and the influence of the French act on the European constitutions seemed to be the primary subject of attention. Second, the sequence in which the American Constitution and the French Declaration were adopted naturally favored the claim of American parentage of the French act. This conclusion seemed to undermine the originality of the French Declaration and irritate the historians who believed that the key ideas of the Declaration were rooted in the philosophy of the French Enlightenment. Moreover, the American draftsmen emphasized the continuity of their constitutional works and eventually looked for roots in the British rather than in the French constitutional ideas and traditions. For these reasons, the American contribution to the process of drafting the French Declaration and the subsequent influence of the French act on the American constitutional development, particularly the formation of the American Bill of Rights, has never received desired attention.

* Article was originally published by "The American Journal of Comparative Law" 1990, vol. 38, Suplement, p. 445-462. 


\section{Interflow of ideas}

The impact of European continental philosophers on the American founding fathers raised many controversies. There were those who wanted to view the American constitutional development as an unprecedented and unique process: one which did not develop from any special historical or intellectual background and those who claimed that the chief spokesmen of the American Revolution were consumers rather than producers of ideas. ${ }^{1}$ The representatives of the second group usually admitted that the American founding fathers drew most fruitfully from antiquity and that despite the fact that the colonies rebelled against their mother country, they respected their British heritage and were dedicated followers of British political thought. ${ }^{2} \mathrm{Al}-$ though Americans stressed that the form of the government of the new republic was not imported from the British Constitution they professed to reverence the British Constitution and at least in the beginning of the struggle for independence, they declared that they were defending their liberties and rights under the British law which was viewed as "perfect in human institutions". ${ }^{3}$ However, American political thinkers, although extracting heavily from British political thought and British constitutional experience, were very selective in whose ideas they followed. ${ }^{4}$ Next to John Locke, the American political philosophers most often cited were Edward Coke, Henry Bolinbroke, William Blackstone, James Harrington, David Hume and Algernon Sidney. ${ }^{5}$

\footnotetext{
${ }^{1}$ Paul M. Spurlin quotes William Gladstone's famous remark in his essay on de Tocqueville's De la démocratie en Amérique that the American Constitution was "the most wonderful work ever struck off at a given time by the brain and purpose of man", and John Stuart Mill's declaration that "the whole edifice was constructed within the memory of man, upon abstract principles". P.M. Spurlin, Montesquieu in America 1760-1801, Luisiana State University Press, University, LA 1940, p. 27. In his observation on De la démocratie en Amérique (1835-1840) Alexis de Tocqueville remarked that the American Constitution was based "upon a wholly novel theory which may be considered a great discovery in modern political science". For further comments, see H. Taylor, The Origin and Growth of the American Constitution, Houghton Mifflin Co., Boston-New York 1911, p. 21. For the opposite opinion, see C. Rossiter, The Political Thought of the American, Harcourt, Brace \& World, New York 1963, p. 65.

${ }^{2}$ For comments on the classical education of the American founding fathers, see A. Hamilton, J. Madison, J. Jay [in:] B.F. Wright (ed.), The Federalist, Wesleyan University Press, Middletown, CT 1961, p. 4; R. Kirk, Edmund Burke and the Constitution, "Intercollegiate Review" 1985-1986, vol. 21, p. 5; see also C. Rossiter, The Political Thought..., supra n. 1 at 10.

${ }^{3}$ For opinions on the British roots of the American constitutional ideas, see D. Malone, Jefferson and the Rights of Man, Little, Brown \& Co., Boston 1953, p. 356; for anglophilism of John Adams, see R.R. Palmer, The Age of the Democratic Revolution: The Challenge, Princeton University Press, Princeton, NJ 1959, p. 275; H. Taylor, The Origin and Growth..., p. 19. It was often claimed that the publication of Thomas Paine's Common Sense in January 1776 and his criticism of the British Constitution contributed to the exposition of the individual attributes of the American system. J. Miller, Origins of the American Revolution, Little, Brown \& Co., Boston 1943, p. 467-493.

${ }^{4}$ C. Rossiter, The Political Thought..., supra n. 1 at 65.

${ }^{5}$ See ibidem, supra n. 1 at 69. On the impact of Locke's ideas, see G. Dietze, The Federalist: A Classic on Federalism and Free Government, Johns Hopkins Press, Baltimore 1960, p. 324-36. The careful reader of The Federalist will discover that the other great political thinkers like Thomas Hobbes, Jeremy Bentham, Robert Filmer and Edmund Burke were almost never directly cited. See C. Rossiter, The Political Thought...,
} 
The impact of European continental philosophers was not as widely admitted. Americans split very frequently in their opinions on the influence of French thought on the founding fathers. As James Breck Perkins wrote,

\begin{abstract}
"By French literature the colonists were unaffected, because, with few exceptions, they knew nothing about it. The number who could read French was small, the number who did read French to any extent was smaller. The political theories of Montesquieu and of Rousseau, the wit of Voltaire, the infidelity of the encyclopedists, had no influence upon men, the most of whom did not know these writers even by name. Our ancestors' modes of thought were essentially English; the political traditions which they inherited, and the political institutions which they founded, were unaffected by French thought". ${ }^{\circ}$
\end{abstract}

Between this extreme statement and the opinions of those who believed that Americans had "taken all their knowledge" from continental European thought, one can easily find a variety of more moderate positions. ${ }^{7}$ For example, even the most militant defenders of the "unique character" of American political thought rarely contested the impact of the French philosopher Montesquieu on the framers of the Constitution of 1787..$^{8}$ The first English translation of Montesquieu's The Spirit of Laws was announced for sale in Boston in 1762, and his Persian Letters were offered to American readers two years later. ${ }^{9}$ The authors of The Federalist frequently mentioned Montesquieu directly but not always favorably. James Madison, in his tenth, fourteenth and thirty-ninth letters, argued that Montesquieu failed to distinguish a republic from a democracy. Alexander Hamilton, in letter nine, maintained that the size of the republic which the author of The Spirit of Laws had in mind would not be applicable to any of the larger states in the American confederation. ${ }^{10}$ Still, the authors of The Federalist praised Montesquieu for his examination and popularization of the English system of government. As Madison wrote,

supra n. 1 at 67; G. Dietze, The Federalist..., p. 319. On the impact of Edmund Burke, see R. Kirk, Edmund Burke..., supra n. 2.

${ }^{6}$ J. Perkins, France in the American Revolution, Hougton Mifflin Co., Boston-New York 1911, p. 418-419; for the influence of Montesquieu and Rousseau, see also P.M. Spurlin, Rousseau in America 1760-1809, University of Alabama Press, University, LA 1969; P.M. Spurlin, Montesquieu in America... Mumford Jones, the author of America and French Culture, 1750-1848, University of North Carolina Press, Chapel Hill 1927, was of a different opinion. He wrote "that the great mass of the American people ever learned enough French to read or speak it does not appear. But, among the cultivated classes from the earliest times there were those who were familiar with the language; and it is from these leaders that ideas and attitudes descended to the rank and file in the United States" (p. 215). Jones observed that the popularity of French reached its height in the years 1770 to 1797 (ibidem).

7 See, E. Laboulaye, Étude sur l'Esprit des Loix, de Montesquieu, "Revue de Droit International et de Legislation Compare" 1869, vol. 1, p. 161, 179.

${ }^{8}$ Francis Newton Thorpe maintained that Montesquieu's The Spirit of Laws had more influence on $18^{\text {th }}$-century American political thought than any other work on govemment. See F. Thorpe, The Constitutional History of the United States, Callaghan \& Co., Chicago 1901, vol. 1, p. 155. "Every literate colonist could quote [Montesquieu] to advantage." C. Rossiter, The Political Thought..., supra n. 1 at 71.

${ }^{9}$ Montesquieu, The Spirit of Laws (published originally in France, 1746; trans. T. Nugent, ${ }^{\text {st }}$ English ed., London 1750; trans. I. Thomas Jr., $1^{\text {st }}$ U.S. ed., London 1902).

${ }_{10}$ B.F. Wright (ed.), The Federalist, No. 9 at 126 (A. Hamilton); No. 10 at 135-36; at 150; No. 39 at 28-86 (J. Madison). 
"The oracle, who is always consulted and cited on this subject, is the celebrated Montesquieu. If he be not the author of this invaluable precept in the science of politics, he has the merit at least of displaying and recommending it most effectually to the attention of mankind". ${ }^{11}$

It must be acknowledged that the admiration of French Enlightenment in America was balanced by the criticism, if not the aversion to the French model of the pre-revolutionary government. ${ }^{12} \mathrm{~A}$ distaste for French monarchy contributed to the fact that in the great debates over the federal constitution, France is scarcely mentioned. ${ }^{13}$ Generally speaking, Americans were convinced that their government was the best that ever did exist and were interested in the French affairs primarily because they believed that through the French Revolution their experience could be spread throughout the globe. ${ }^{14}$

The American struggle for independence occurred at the most opportune time when France's traditional desire to curb British power coincided with the intention to compensate for the losses suffered in the Seven Years' War. The American Revolution was also proof that liberal ideas of Enlightenment had spread all over the world. As James B. Perkins wrote, "For those who claimed abuses of [the] old regime, the Revolution in America seemed to be [the] best proof that those regimes had to die". ${ }^{15}$

American interests were well-represented in France by Benjamin Franklin, Arthur Lee, and Silas Deane. Franklin's arrival in France in December 1776 was an important event. Since 1772, he had been a member of the French Academy and was preceded by the reputation of philosopher and scientist. He spoke French fluently and his connections with French philosophers were widely known. ${ }^{16}$ According to Henry S. Commager:

${ }^{11}$ Ibidem, No. 47 at 337 (J. Madison). Montesquieu was also widely cited by the critics of the Constitution. See The Cato Letters published by Governor George Clinton. Seven letters were published in the "New York Journal" between September $27^{\text {th }}, 1787$ and January $3^{\text {rd }}, 1788$. They are reprinted in P.L. Ford (ed.), Essays on the Constitution of the United States, Historical Printing Club, Brooklyn, NY 1892, p. 247-78.

${ }^{12}$ For comments on Jefferson's first observations on the government of France, see Ch.D. Hazen, Contemporary American Opinion of the French Revolution, P. Smith, Gloucester, MA 1964, p. 6-7. Jefferson was convinced that France was politically backward. He wrote, "I presume there are not to be found five men in Europe who understand the nature of liberty and the theory of government so well as they are understood by five hundred men in America." Ibidem, p. 37. In his letter to John Melish of January 13 $3^{\text {th }}, 1813$, he wrote, "They [the party called republican] esteem the people of England and France equally, and equally detest the governing powers of both". A.T. Mason, Free Government in the Making. Readings in American Political Thought, $3^{\text {rd }}$ ed., Oxford University Press, New York 1965, p. 384.

${ }_{13}$ R. Ketcham, France and American Politics 1763-1793, "Political Science Quarterly" 1963, vol. 78, p. 2, 217.

${ }^{14}$ Hazen observed that the French Revolution became a more frequent topic to be discussed in state rather than federal papers. Ch.D. Hazen, Contemporary American..., supra n. 12 at 246. See R.B. Morris, The Emerging Nations and the American Revolution, Harper \& Row, New York 1970, p. 17. For Jefferson's opinion that the American model of government is "without comparison the best existing or that ever did exist", see D. Malone, Jefferson and the Rights... See letter of Richard Price to Jefferson, dated May $4^{\text {th }}, 1789$, published in J. Boyd (ed.), The Papers of Thomas Jefferson, Princeton University Press, Princeton, NJ 1958, p. 91 (hereinafter Jefferson Papers).

15 J. Perkins, France in the American..., supra n. 6 at 209.

${ }^{16}$ Ibidem, p. 126. For an examination of the intellectual factors regarding the rise of the revolutionary spirit in France, see D. Mornet, Les Origins intellectuells de la Révolution française 1715-1787 (Paris 1933); 


\begin{abstract}
"It was France that welcomed the American example - welcomed it, followed it, and even improved upon it. It was in France that the »American party« triumphed, briefly, to be sure; the party made up somewhat loosely of LaFayette, la Rochefoucauld, Brissot, Condorcet, Beaumarchais, Du Pont de Nemours, Helvetius, the Abbes Sieyes, Raynal, and Mably. A miscellany of other - followers of Turgot and converts to his doctrines of Physiocracy and of Progress, members of the Amis des Noirs, of the Club Americans, or the Masonic Lodge of the Nine Sisters. Franklin was the pivotal point, Franklin who was a legend, but a very active one, and who saw to it that the American Constitution and other State Papers, were translated and published in France." ${ }^{17}$
\end{abstract}

Franklin was very successful in representing the American case. Supported by Pierre A.C. Beaumarchais' efforts, he processed significant financial assistance for the rebellious colonists and successfully conducted negotiations which were concluded by the French alliance and signed with the United States in early 1778 . His presence in France encouraged a great number of Europeans (such as Marquis LaFayette, Baron Kalb, and a Pole, Pulaski) to offer their services to the new republic. ${ }^{18}$ The French emotional and financial involvement in the American War was so significant that some of the pamphleteers claimed that it was the American Revolution, its cost and opinions created by the supporters which forced Louis XVI to call the Estates General. ${ }^{19}$

Life in America was romanticized and idealized in a number of books and pamphlets such as Lettres d'un Cultivateur American (1784) which depicted the charms of the wild but happy and digni- fied life in the big country, uncontaminated by civilization. ${ }^{20}$ The increasing popularity of the American style of life and the ideas of the

W. Doyle, Origins of the French Revolution (Oxford 1980). For an examination of the contribution of social groups to the emergence of the revolutionary movement, see A. Cobban, The Myth of the Revolution (London 1955), Social Interpretation of the French Revolution (Cambridge 1964) and Aspects of the French Revolution (New York 1968). For a social and economic interpretation of the Revolution, see G. Lefebvre, Quartre-Vingt-Neuf (Paris 1939) (trans. R.R. Palmer, 1947); G. Lefebvre, R. Guyot and Ph. Sagnac, La Révolution française (Paris 1930) (trans. E. Moss Evanson, 1962); G. Lefebvre, Études sur la Révolution française (Paris 1954).

${ }_{17}$ H.S. Commager, The Empire of Reason: How Europe Imagined and America Realized the Enlightenment, Anchor Press/Doubleday, Garden City, NY 1977, p. 243; quote after A.P. Blaustein, The Influence of the United States Constitution Abroad, Washington Institute, Washington DC 1986, p. 10. The new legislative texts from America were carefully distributed by Franklin and Jefferson in Paris, and John Adams in London and The Hague. For further detail, see J.L. Godechot, France and the Atlantic Revolution of the Eighteenth Century 1770-1799, Free Press, New York 1965, p. 45. Some of these texts were published in "Les Affaires de L'Angleterre et de L'Amérique", a periodical published both in Antwerp and Paris. In 1790 French lawyer Jacques Vincent de la Croix offered a course on the Constitution of the United States at the "lycée de Paris." The materials from the course were published by the popular Paris newspaper "Le Moniteur". See, A.P. Blaustein, The Influence..., p. 13 and 16.

${ }^{18}$ For comments on Franklin's stay in France, see Ch.D. Hazen, Contemporary American..., supra n. 12 at 1. On Franklin's meeting with Voltaire, see R.B. Morris, The Emerging Nations..., supra n. 14 at 44-45. Palmer wrote, "Franklin, Jefferson, and Adams, along with men like Lafayette and Kosciuszko, were only the most eminent among thousands who served, in their own persons, as channels of communication between America and Europe." R.R. Palmer, The Age of the Democratic..., supra n. 3 at 252.

${ }^{19}$ Le Compte de Vergennes, Cause des États généreux (1788); see also B. Fay, The Revolutionary Spirit in France and America, Harcourt, Brace \& Co., New York 1927, p. 253.

${ }_{20}$ The author was most probably Hector Saint-Jean de Creveceur. See B. Fay, The Revolutionary Spirit..., supra n. 19 at 232-233. On idealization of America, see also R.R. Palmer, The Age of the Democratic..., supra n. 3 at $257-259$. 
American republic also had critics, led by Jacques Mallet du Pan, editor of the Mercure de France, who strongly attacked French involvement abroad. ${ }^{21}$

\section{American contribution to the french declaration of rights}

In the year before the breakdown of the old Regime, friends of the American cause frequently gathered either in LaFayette's hotel in Paris or in the house occupied by Thomas Jefferson, who in 1784 was sent to assist Franklin and in 1785 replaced Franklin as a minister to France. Jefferson remained in France until 1789. ${ }^{22}$ The French fascination with America reached its highest peak in the several months preceding the adoption of the French Declaration of the Rights of Man and Citizen. During this period, the political work of the American Revolution was most extensively discussed. Before 1789, four editions of the U.S. Constitution had previously been published. The American state constitutions also inspired a broad interest. The Frenchmen were most attracted to the constitution of Pennsylvania, which provided for a unicameral legislative system and executive power entrusted to a president, chosen by the legislature and assisted by a council of twelve. The Pennsylvania Constitution was praised in France as the most democratic constitution adopted anywhere. ${ }^{23}$ As Albert P. Blaustein argued, "France's first constitution (...) looked more to Pennsylvania than to any other United States source for its governmental structure". ${ }^{24}$ In regard to other American state constitutions, those of Virginia, Massachusetts and Maryland were most widely discussed. It was often raised that the preambles of these constitutions as well as their prototype, the American Declaration of Independence, strongly influenced the authors of the French Declaration. As Bernard Fay wrote, "A detailed comparison of the French Declaration of Rights with the preambles of these three constitutions brings out a striking resemblance". ${ }^{25}$ This thesis was ques-

${ }^{21}$ See J. Mallet du Pan, Considerations on the Nature of the French Revolution, H. Fertig, New York 1974, p. X.

${ }^{22}$ The most frequent visitors at Jefferson's house were Mounier, Lally, Rabaut, Duport, Lameth and Barnave. See B. Fay, The Revolutionary Spirit..., supra n. 19 at 256.

${ }^{23}$ See J.L. Godechot, France and the Atlantic..., supra n. 17 at 35.

${ }^{24}$ A.P. Blaustein, The Influence..., supra n. 17 at 8; H.S. Commager, The Empire of Reason..., supra n. 17 at 243-244. The idea of a unicameral legislative body was advocated for France by Franklin and Turgot. See M. Jones, America and French..., supra n. 6 at 528. Governor Morris was of a different opinion. He spoke against the removal of all political power from the French king and about "the anarchy which would result from giving the wretched constitution of the Pennsylvania legislature to the Kingdom of France." A.C. Morris (ed.), Diary and Letters I at 38. Despite that, Morris found that "the American example had powerfully affected the attitude of French thought toward liberty, equality and constitutional popular government", yet he feared that the French, "lacking experience and poise, would seek to apply these new and seductive ideas in an arbitrary way with dangerous disregard of changed conditions." Ch.D. Hazen, Contemporary American..., supra n. 12 at 82 . The idea of a unicameral legislature modeled on the Pennsylvania constitution was also criticized by John Adams. See M. Jones, America and French...

${ }^{25}$ B. Fay, The Revolutionary Spirit..., supra n. 19 at 266-267. Blaustein, supporting this opinion, wrote, "Thus, while the famous French Declaration of the Rights of Man and the Citizen of August 1789, was offi- 
tioned by French historians who, like Godechot argued that, "The French Declaration of the Rights of Man and Citizen offers some significant differences from the American declarations". ${ }^{26}$ Godechot maintained that the American and French Declarations vary in character. The American texts were to be "very specific, very American", while the French Declaration was conceived as a sort of universal manifesto appealing to mankind as a whole. ${ }^{27}$ In Mirabeau's words, the French declaration was to be "applicable to all ages, all peoples, all moral and geographic latitudes". ${ }^{28}$

The dispute concerning the origins of the French Declaration resulted in the polarization of the positions taken by the disputants, who usually either attempted to trivialize or overestimate the reception of the American patterns..$^{29}$ In fact, the arguments of both disputing parties are not fully convincing and the truth about the origins of the Declaration lays somewhere in between. It is unquestionable that there was a constant interflow of ideas between the two countries and that Frenchmen were attracted to American political arrangements. The idea of the bill of rights, which could be used as a preamble to a constitution, was American and in fact Americans translated it into the idea of a constitution as a single document providing a basic law superior to any legislative act and different from mere statutes. Also the idea that a constitution should be passed or amended by special

cially the work of LaFayette, Mirabeau, and Jean Joseph Mounier, it also had claim to American parentage." A.P. Blaustein, The Influence..., supra n. 17 at 16.

${ }^{26}$ J.L. Godechot, France and the Atlantic..., supra n. 17 at 96.

27 Ibidem.

${ }^{28}$ Quote from ibidem. The careful examination of the debates in the French Constitutional Assembly confirms that the deputies believed that they framed a manifesto which was more than a transcription of the ideas of the great philosophers and, in fact, had universal significance. The Declaration of the Rights was to proclaim the commonly recognized immortal principles of the new age. For debates on the Declaration, see J. Mavidal, E. Laurent et al. (eds.), Archives parlementaires de 1787 à 1860, Paris 1862-1913, vol. 8, p. $221 \mathrm{ff}$. A demand for a universal declaration of rights was also confirmed in many of the cahiers which were widely recognized as a guide indicating the sphere of a national consensus. Cahiers de doleances were the lists of grievances which were drafted during the elections to the Estates General by the electoral assemblies of the French provinces, separately by each estate. The $\mathrm{ca}$ hiers, although not treated by the Constitutional Assembly as imperative instructions for deputies, had informational and psychological influence. The cahiers were studied carefully by the Committee on the Constitution and an official Summary of the Cahiers was presented in the Assembly on July $27^{\text {th }}, 1789$ by the Clermont-Tonnere, Deputy of North Paris. The Summary, which in fact presented an incomplete list of claims and dealt predominantly with the constitutional issues, did not mention the declaration. The demand for a declaration was, however, so widely recognized that the Assembly on August $4^{\text {th }}$, began to work on the list of basic rights. See B. Fry Hyslop, A Guide to the General Cahiers of 1789 with the Texts of Unedited Cahiers, Columbia University Press, New York 1936, p. 104. For official Summary of the Cahiers, see L.G. Wickham Legg, Selected Documents Illustrative of the History of the French Revolution. The Constituent Assembly, Clarendon Press, Oxford 1905, vol. I, p. 103-104. See also J.L. Godechot, France and the Atlantic..., supra n. 17 at 95.

${ }^{29}$ Overestimating the resemblance of the American and French documents Richard Morris wrote, "The Virginia statesman George Mason might well have instituted an action of plagiarism against the authors of the Declaration of the Rights of Man and the Citizen which the French National Assembly adopted on August $26^{\text {th }}, 1789$. The resemblance to Mason's Bill of Rights which the Virginia Assembly had enacted back in June of 1776 is too close to be coincidental." R.B. Morris, The Emerging Nations..., supra n. 14 at 56. 
conventions or with requirements higher than those expected for ordinary statutes was worked out in America. ${ }^{30}$

The original draft of the Declaration was prepared by LaFayette, discussed with Jefferson, and sent to Madison for comment. ${ }^{31}$ The draft was also studied by Governor Morris who was in Paris occasionally on private business. ${ }^{32}$ Before preparing his draft, Lafayette also discussed the subject with Hamilton, Franklin and Thomas Paine. However, the first Lafayette draft was not met with an enthusiastic reception. The draft generated heated dispute during which some deputies even proposed not to publish the Declaration until the adoption of the Constitution. ${ }^{33}$ Finally, the Assembly accepted a draft which was a compromise between Lafayette's initial project and drafts of other deputies such as Sieye's, Mirabeau's and Mounier's, which were most widely discussed and influential. The compromise brought more French tincture to the Declaration. ${ }^{34}$ The literal comparison of the Declaration of the Rights of Man and Citizen with the American Declaration of Independence and the Virginia Bill of Rights brings us to conclusions, which would urge revision or modification of several popular opinions.

It was often advanced that the Declaration of the Rights of Man more markedly attached equality to liberty and stressed the importance of this conjunction more than the American Declaration of Independence or the Virginia Bill of Rights. According

${ }^{30}$ See Ch. Warren, Congress, The Constitution and the Supreme Court, Little, Brown \& Co., Boston 1925, p. 14-16, and 87.

${ }^{31}$ See A.P. Blaustein, The Influence..., supra n. 17 at 16. In January, 1789 Jefferson had written Madison that he contributed to framing a declaration of rights and had sent two drafts, including one by Lafayette. P.L. Ford (ed.), The Writings of Thomas Jefferson, Thomas Jefferson Memorial Association of the United States, Washington, DC 1892-1899, vol. V, p. 64. Jefferson had also a copy of a draft submitted by Dr. Richard Gem, an Englishman, successful physician, and ardent devotee of republican principles. See "Proposition submitted by Richard Gem" and Jefferson's letters to James Madison (Sept. $6^{\text {th }}, 1789$ ) and to Richard Gem (Sept. $9^{\text {th }}, 1789$ ). Jefferson Papers, supra n. 14 at 384-399. In July, before presenting a declaration to the Assembly, Lafayette sent another draft to Jefferson. Malone, supra n. 14 at 223. Lafayette's draft of a Declaration of Rights is published in Jefferson Papers, supra n. 14 at 230-233.

${ }^{32}$ Morris arrived in France in February 1789 and remained in Europe for nine years. He was appointed U.S. Minister to France in 1792.

${ }^{33}$ Lafayette's draft was more general than the final text of the Declaration. The draft declared that men are made free and equal by nature. The draft enumerated natural and inalienable rights of man. It declared rights to speak, write, free communication of ideas, and religious freedom. It stated that natural rights are confirmed by the society and that the source of sovereignty resides in the nation. The draft, however, focused on the concept of representative government and the separation of powers - problems which were only generally mentioned in the final text of the Declaration but were in fact addressed by the Decree of October $1^{\text {st }}, 1789$ and the Constitution of 1791 . On the other hand, the final text of the Declaration went further in explaining the ideas of "equal freedom", presumption of innocence, personal and property inviolability, due punishment, and maintenance of public force. In neither the draft nor the final text of the Declaration was there room for the concept of trial by jury which was strongly advocated by Jefferson. Jefferson Papers, supra n. 14 at 233.

${ }^{34}$ See G. Lefebvre, The French Revolution from Its Origins to 1793, Routledge \& K. Paul, London 1962, p. 146. The most exhaustive comparison of the French Declaration and the Virginia Bill of Rights was presented by Palmer in Appendix IV to The Age of Democratic Revolutions, supra n. 3 at 518-521. The comparison brings Palmer to the conclusion that "there was in fact a remarkable parallelism" between both acts. R.R. Palmer, The Age of the Democratic..., p. 487. 
to Professor Lefebvre, "By bringing the resounding collapse of privileges and feudalism, the popular revolution highlighted equality as the Anglo-Saxons had not done". ${ }^{35}$

Article 1 of the French Declaration proclaimed that "men are born free and equal in rights". ${ }^{36}$ Equality is also referred to in several of the following Articles. ${ }^{37}$ The Declaration guaranteed equal rights in courts, equal access to government positions, and fiscal equality. With all these egalitarian provisions, one has to admit that equality, although emphasized more firmly than in the Anglo-Saxon doctrine, "holds a lesser place than freedom in the [French] Declaration" ${ }^{38}$ Liberty is by far the most important right among the fundamental principles of 1789-1791. Men are declared free from arbitrary persecution and may communicate their opinions, provided they respect the same liberty of others. Liberty as well as property, security, and resistance to oppression are recognized as the fundamental individual rights stemming from the nature of human beings. ${ }^{39}$ Equality does not figure among these sacred and imperceptible rights. The French Assembly focused on the condemnation of the unequal position of estates and privileges of minorities, and following Sieyes' argument, decided not to include social equality among the rights protected by the Declaration. Contrary to the second French Constitution of 1793 which stressed the significance of social equality, the majority of the Constitutional Assembly in 1788-1791 was satisfied with the protection of equal freedom which was defined as the right to do what does not harm the others. The right of "equal freedom" was formulated more clearly in the Constitution of 1791 than in the Virginia Bill of Rights. On the other hand,

35 Ibidem.

36 The American Declaration of Independence states that "all men are created equal, that they are endowed by their Creator with certain unalienable Rights." The Virginia Bill of Rights of 1776 declared " $[\mathrm{t}]$ hat all men are by nature equally free and independent, and have certain inherent rights." F.N. Thorpe (ed.), The Federal and State Constitutions, Government Printing Office, Washington 1909, vol. 7, p. 3813 (hereinafter Virginia Bill of Rights).

37 Declaration des droits de l'homme et du citoyen [in:] J.M. Roberts, R.C. Cobb (eds.), French Revolution Documents, Blackwell, Oxford 1966, p. 171-173 (hereinafter Declaration).

38 J.L. Godechot, France and the Atlantic..., supra n. 17 at 96 . On the one hand, the idea of equality appealed to the American sense of justice. On the other hand, they feared that in practice it would collide with individual freedom. Generally they were satisfied with equality before the law and felt uncomfortable with the French attempts to extend equality to social and economic relations. "By the law of nature - wrote John Adams - all men are men and not angels - men and not lions - men and not whales - men and not eagles - that is, they are all of the same species. And this is the most that the equality of nature amounts to. But man differs by nature from man almost as much as man from beast. The equality of nature is moral and political only and means that all men are independent." Ch.D. Hazen, Contemporary American..., supra n. 12 at 274-275. On the limits of American dedication to the creation of an egalitarian society, see R.B. Morris, The Emerging Nations..., supra n. 14 at 21-22.

39 In 1789, the French Assembly generally showed a stronger sensitivity to egalitarian values than did the framers of the American Declaration. Still, it was to take several years to turn this sensitivity into a fully expressed egalitarian program. Attacks from the socialists - like Mably or Morelly on private property or Rousseau's well-known criticism of the law as the instrument of exploitation and his accusation of excessive accumulation and unequal distribution of property - did not find an endorsement in 1789 . The Assembly recognized property as sacred (Article 17) and established a representative system based on a property qualification. For more exhaustive comments, see M. Kingsley, French Liberal Thought in the Eighteenth Century, Phoenix House, London 1962, p. 220-258. 
the Virginia Declaration placed great emphasis on freedom and frequency of elections and on jury trial and was more concrete in the warnings against excessive bail and more explicit in reference to general warrants, suspending of laws and standing armies. ${ }^{40}$

In further assessing the American and French Declarations, it was often raised that a number of the deputies of the French Assembly led by Robespierre were dissatisfied with the insufficient treatment of religious liberty and religious toleration in the French Declaration.

The American Declaration of Independence referred to the Creator since Americans were generally known for their attachment to religion. On the other hand, given this dedication to religious freedom they were determined not to grant priority to any religion. The writers who were inclined to expose the different character of the American and the French Declarations argued that, contrary to the American revolutionary acts, the French Declaration of Rights did not pay sufficient attention to religious liberty and by placing itself under the auspices of the Supreme Being the Declaration intended to preserve the primacy of the Catholicism. ${ }^{41}$ The fact that the Assembly was satisfied with the mild reference to religious toleration was recognized as a failure of the Voltaireans during this phase of the Revolution.

These arguments can be accepted only with some reservations. First of all, although religious matters were not discussed in the Declaration of Independence, they were duly recognized in the state's bills of rights. The Virginia declaration proclaimed that [there existed] "the duty which we owe to our Creator." Generally Virginia Bill of Rights was more explicit than the French Declaration in reference to Christian and moral virtues. ${ }^{42}$ Secondly, in revolutionary France the diffusion of Voltaire's works was enormous and his influence can hardly be overestimated. ${ }^{43}$ Soon after the adoption of the Declaration, the French Assembly promulgated a series of acts relating to the ecclesiastical reorganization. Recognizing the significance of the principle of religious liberty and equality, the Assembly granted religious liberty to Protestants. The Decree of December $2^{\text {nd }}, 1789$ declared the confiscation of property of the Catholic Church. In addition, the most important Civil Constitution of the Clergy, adopted on July $12^{\text {th }}, 1790$, drastically limited the dependence of the French Catholic Church on the Pope and tied the clergy through the prescribed oaths, salaries and newly established ecclesiastical districts to the state. ${ }^{44}$ These acts passed by the Assembly appeared to confirm the influence of the Voltairean secular rationalism on the minds of the people during the preconstitutional phase of the French Revolution. France remained a predominantly Catholic country. This simple fact toiled the

40 See R.R. Palmer, The Age of the Democratic..., supra n. 3 at 520.

${ }^{41}$ For more detail on the disputes in the Assembly, see Archives, supra n. 28 at 221 ff.; see also J.H. Stewart, Documentary Survey of the French Revolution, Macmillan, New York 1951, p. 115-117.

42 See R.R. Palmer, The Age of the Democratic..., supra n. 3 at 520.

43 Between 1778 and 1935, thirty-four complete editions of his works and numerous incomplete ones were publsihed.

${ }^{44}$ J.H. Stewart, Documentary Survey..., supra n. 41 at 167-189. 
servile adoption of the American models. On the other hand, it must be conceded that with the development of the French Revolution, Americans were more and more concerned about "the air of atheism" and French hostility to religion. Commenting on this trend, John Adams admitted that the French drew more from their own philosophy than from American experience. In a letter to Dr. Price, he concluded, "I own to you I know not what to make of a republic of thirty million atheists.".

As often suggested, the more populist character of the French Declaration of Rights was rather apparent than real. The American Declaration of Independence stated that governments derive "their just powers from the consent of the governed". The French text was more explicitly Rousseauistic by proclaiming that "law is the expression of the general will". ${ }^{6}$ In fact, however, both Declarations were Rousseauistic only from these phrases. As manifestos of developing liberalism, they proclaimed a victory of the individualistic philosophy. This philosophy recognized an individual, man, or citizen to be a subject of fundamental rights. His individual autonomy was proclaimed as being worthy of constitutional protection. An individual was declared as the best judge of his own well-being and the interests of the community were recognized as the sum of individual interests. ${ }^{47}$

The framers of both Declarations followed Rousseau's concept of general will only by name. The American Declaration of Independence focused on the reasons for which the thirteen original states severed their colonial allegiance. The interpretation of the principle of the popular origin of power was left to constitutional regulation which fully recognized the representative form of government. The French Declaration, which was itself conceived as a preface to the Constitution, more explicitly explained the idea of representation. For most of the deputies, sovereignty was indivisible and inalienable but the sovereign people could exercise their power through elected representatives. Article 6 of the Declaration reads as follows:

"Law is the expression of the general will; all citizens have the right to concur personally, or through their representatives, in its formulation; it must be the same for all, whether it protects or punishes. All citizens, being equal before it, are equally admissible to all public offices, positions, and employments, according to their capacity and without other distinction that of virtues and talents". ${ }^{48}$

${ }^{45}$ Ch.D. Hazen, Contemporary American..., supra n. 12 at 152-153. In fact, French religious instability greatly affected American attitudes. The fluctuations from religious infidelity to the orthodoxy of the Jesuits and ultramontanism of J. de Maistre scared Americans. "France, instead of being a country to admire and pattern after was now a nation to pity and dispise." M. Jones, America and French..., supra n. 6 at $447-48$.

${ }^{46}$ Declaration, Article 6.

47 The concept of "general will" (la volonté générale) was basically anti-individualistic. It was discussed by Montesquieu, Holbach, Diderot, and other philosophers, but Rousseau was recognized as its main proponent. For Rousseau, the general will was indivisible, and inalienable. It embodied the interests of society as a whole. For Rousseau's influence on the French Revolution, see J. McDonald, Rousseau and the French Revolution 1762-1791 (London 1965); J.L. Talmon, The Origins of Totalitarian Democracy (New York 1960); A. Meynier, J.J. Rousseau, révolutionnaire (Paris 1911).

${ }^{48}$ Our emphasis. 
Sieyes' opinion prevailed in the Assembly. He advocated that deputies were representatives and not only 'intermediaries'. He stressed that the majority of them had the right to decide, and that the will of the majority meant the sum of the individual wills of its members. It was Sieyes who, in his popular pamphlet Qu'est-ce le Tiers Etat, argued that "individual wills are the sole elements of the general will" and that, "it is useless to talk reason if, for a single instant, this first principle, that the general will is the opinion of the majority, is abandoned". ${ }^{9}$

Summarizing, one has to admit that although the resemblance between the French and American Declarations is remarkable, they differ in the emphasis given to particular rights. The literal comparison of the texts does not deprive the Declaration of the Rights of Man and Citizen of its very special French character.

\section{The french declaration of the rights of man and citizen and the american bill of rights}

The American Federal Convention adopted the Constitution without a bill of rights prefixed to it. So it departed from the format which had previously existed in some of the states. The motion of George Mason and Elbridge Gerry to preface the Constitution with a bill of rights was opposed by Roger Sherman of Connecticut on the ground that " $[t]$ he State Declarations of Rights are not repealed by this Constitution; and being in force are sufficient". ${ }^{50}$ The argument that the Congress should be trusted in its intention to preserve the rights of the people was convincing for the delegates of the Convention who unanimously (voting as state units) opposed the motion to form a bill of rights committee. ${ }^{51}$

The struggle for the ratification of the Constitution promptly proved that the Federal Convention erred in the evaluation of public expectations. The demand for a bill of rights was widespread. The requirement of a bill of rights became a main point in the Antifederalists attack on the Constitution. ${ }^{52}$ Jefferson, in his letters from France, argued strongly that the lack of a bill of rights might result in the "elective despotism" of the Congress. Madison was generally in favor of a bill although he did not believe

${ }^{49}$ Translation and reprint by J.H. Stewart, Documentary Survey..., supra n. 4 at 50.

${ }^{50}$ R.A. Rutland, The Birth of the Bill of Rights 1776-1791, University of North Carolina Press, Chapel Hill 1955, p. 116.

${ }^{51}$ Ibidem.

${ }^{52}$ See M. Smith, An Address to the People of the State of New York of 1788 [in:] P.L. Ford (ed.), Pamphlets on the Constitution of the United States Published during its Discussion by the People 1787-1788, Brooklyn Historical Club, Brooklyn 1888, p. 114. Antifederalist Whitehill argued at the Pennsylvania Ratifying Convention, 1787 that "he anticipates annihilation of the state governments which would destroy civil liberties." A.T. Mason, Free Government in the Making. Readings in American Political Thought, Oxford University Press, Oxford 1965, p. 267-273. For arguments of Antifederalist Lenoir in the North Carolina Ratifying Convention, see ibidem, p. 275. 
the omission to be a major defect of the Constitution. ${ }^{53}$ The Constitution was ratified with the general understanding that "the amendments proposed will soon become a part of the system". ${ }^{4}$

On May $4^{\text {th }}, 1789$ Madison gave notice to Congress that he intended to bring forth the subject of amendments to the Constitution. ${ }^{55}$ Madison made his statement a day before the French Estates General met for the opening plenary session in the great Salle des Menus Plaisirs. In fact, the record shows that the drafting actions of the French Declaration and the American Bill of Rights almost paralleled each other. Madison submitted his draft on June $8^{\text {th }}$ and Lafayette presented his proposal to the French Assembly on July $11^{\text {th }} .^{56}$ On August $13^{\text {th }}$, the U.S. House of Representatives resolved itself into a Committee of the Whole and discussed the report of the Committee of Eleven to whom the subject of the amendments was referred. The special Committee of Three (Benson, Sherman and Sedgwick) submitted the Report with the Third Draft of the Amendments on August $24-25^{\text {th }}$, two days before the French Assembly adopted the Declaration of the Rights on August $27^{\text {th }}, 1789 .{ }^{57}$ The Amendments passed Congress on September $25^{\text {th }}, 1789$.

The American Bill of Rights was ratified on December $15^{\text {th }}$, 1791, but the drafting process was completed before the adoption of the French Declaration. The record shows clearly that the draftsmen of the Bill of Rights could not be influenced directly by the final text of the French Declaration. They could be, however, familiar with its early drafts and inspired by the French constitutional debates. A thorough examination of the record does not confirm this thesis. It is true that the American public was enthusiastic about the French Revolution and the founding fathers were wellinformed about the European events. There is, however, no evidence that they were ready to draw from the French constitutional thought. The works on the French Declaration were hailed in America as an example that Europe had followed the American model. In fact, however, even the idea that France gave America philosophy and America gave her experience was not popular among the American draftsmen who preferred to believe that their constitutional concept grew out of the British seeds..$^{58}$ As F.N. Thorpe wrote,

${ }^{53}$ Jefferson letter to Madison, December 20 $0^{\text {th }}, 1898$ and Madison letter to Jefferson, October $20^{\text {th }}, 1788$. Ibidem, p. 329-320. See also Ch. Warren, Congress..., supra n. 30 at 81.

${ }^{54}$ For Samuel Adams at Massachusetts Convention, see A.T. Mason, Free Government..., supra n. 52 at 310 .

${ }^{55}$ The Debates and Proceedings in the Congress of the United States, vol. I, Gales and Seaton, Washington 1934, p. 247 (hereinafter Annals).

${ }_{56}$ Annals, supra n. 55 at 424-48; Jefferson Papers, supra n. 14 at 230-231.

${ }^{57}$ Annals, supra n. 55 at 88, 913; F. Thorpe, The Constitutional History..., supra n. 8 at 257-259; J.H. Stewart, Documentary Survey..., supra n. 41 at 112-114.

${ }^{58}$ Hazen claims that there were some Americans like Jefferson who believed that "America might well be the teacher of her elder sister in some respects, and these men thought that she might equally well be her pupil in others." Ch.D. Hazen, Contemporary American..., supra n. 12 at 143. It seems that with the progress of the French Revolution the belief in the possibility of learning from France was clearly fading in America. 
"Turning to their sources, the first ten [amendments], are clearly, as Jefferson declared they ought to be, a Declaration of Rights, and each may be said to have emanated from a common source, the State constitutions, or the 'ancient and undoubted rights' of Englishmen". 59

Discussing the historical background of his draft, Madison returned to precedents of the American Declaration of Independence, state constitutions and state bills of rights, to ratifying conventions and the British constitutional documents, Magna Carta (1215), Petition of Rights (1628) and Bill of Rights (1689). ${ }^{60}$ Madison admitted that the concept of a bill of rights originated from the attempts to limit the power of the British Crown. He claimed, however, that Americans had to work out a more advanced Bill of Rights because the British constitution did not secure freedom of press and liberty of conscience ${ }^{61}$ - rights highly esteemed in America. Congress made no reference to the French constitutional experience with exception to the consular convention and the letter to the French National Assembly in relation with Franklin's death. France was hardly mentioned during the first year of debates of the First U.S. Congress.

\section{French revolutionary experience and american politics after 1789}

The French Constitution of 1791 received favorable attention by the American public. The House praised the Constitution for its "wisdom and magnanimity" but the Senate withdrew "magnanimity" from its statement and simply acknowledged the fact of adoption. ${ }^{62}$ This symbolic gesture seemed to begin the process of the polarization of the positions taken by the commentators of the French events who in the next years were to split distinctly into two groups: those coupling and those separating

${ }_{59}$ F. Thorpe, The Constitutional History..., supra n. 8 at 330.

${ }^{60}$ Annals, supra n. 55 at 431-42. Taylor wrote that "[i]f anything is certain in the history of any country it is that the essence of the English constitutional system as reformed by the Revolutions of 1640 and 1688 and as defined by Blackstone in 1758, passed into our first state constitution, whose bill of rights set forth, for the same time, in a written and dogmatic form, the entire scheme of civil liberty as it existed in England in 1776." H. Taylor, The Origin and Growth..., supra n. 1 at 361.

${ }^{61}$ Ibidem, at 436. The British Bill of Rights of 1689 did not proclaim the freedom of speech. It provided only that "the freedom of speech and debates or proceedings in Parliament ought not to be impeached or questioned in any court." E.C.S. Wade, Constitutional Law, Longman, London 1970, p. 8. The American founding fathers correctly viewed the origins of the bills of rights in the procedures and institutions established to limit the power of government. From this point of view, it is quite natural that they looked for precedents in the British constitutional traditions rather than in the history of the French absolutism. In fact, however, they overlooked the constitutional experience of other European countries, such as Poland which had a four-and-a-half-century-long tradition of struggle to restrain the king's power and to create institutions fundamental to a constitutional government. In fact, the Polish nobility had their "Habeas Corpus Act" much earlier than did the nobility in other European countries and had its due process clause well established at the beginning of the fifteenth century. See R.R. Ludwikowski, Two Firsts: A Comparative Study of the American and the Polish Constitutions, "Michigan Yearbook of International Legal Studies" 1987, vol. 8, p. 121.

${ }^{62}$ Annals, supra n. 55, March 1792. For critical comments of Governor Morris, see G.L. Lycan, Alexander Hamilton, "American Foreign Policy" 1970, p. 138. 
the American and French Revolutions. The first group led, by Paine and Jefferson, assumed and emphasized that the French uprising was an afterglow of the American struggle for liberty and had "produced incalculable blessings to that country [France]" and "promoted interests of thousands". ${ }^{63}$ The second faction which assembled around Hamilton preferred to believe that the French Revolution was the outbreak of an unruly and ignorant populace. They believed that the revolution, particularly in its Jacobinian stage, lacked legality and could endanger the achievement of American struggle for freedom. ${ }^{64}$ Hamiltonians were terrified by the changing teams of the French leaders, general defiance of authority, symptoms of anarchy and violence, and lack of security of property. In their conclusions, the French Revolution discredited democracy. ${ }^{65}$

Although the French Constitution of 1793 was widely criticized by the American statesmen, the attitudes of the public were still enthusiastic mostly due to the activity of the democratic societies which mushroomed all over the country. These democratic clubs which approved wholeheartedly all that was happening in France were able to hold for some time a large part of public opinion in favor of the French Revolution. In fact, the activity of the societies intensified a critical reaction of the Washingtonian leaders and helped the Federalists to neutralize pro-French enthusiasm.

In 1793 the French Revolution became a major issue in American politics. It contributed to the crystallization of the line which separated the two emerging parties. ${ }^{66}$ In 1793, when France began to seize American ships the war seemed inevitable. In light of Jay's mission to England, the Federalists could celebrate at least temporary victory of their anti-French politics. In fact, the contest between the two parties blocked the influence of the French Revolution in America. Although the French Constitution of 1795 was favorably construed as an attempt to return to the patterns set by the American Revolution, the momentum of the French influence was lost. The Constitution of 1795 supplemented the Rights of Man with nine paragraphs on the duties of the citizen. However, the subsequent Napoleonic constitutions were more pragmatic and they dropped the sections on the Rights of Man along with a great quantity of the ideology which had sanctioned them. ${ }^{67}$ According to David M. Potter,

${ }^{63}$ See A.T. Mason, Free Government..., supra n. 52 at 420; D. Malone, Jefferson and the Rights..., supra n. 14 at 355-156; G.L. Lycan, Alexander Hamilton, supra n. 62 at 132.

${ }^{64}$ R.R. Palmer, The Age of the Democratic..., supra n. 3, vol. II at 525.

${ }^{65}$ R.B. Morris, The Emerging Nations..., supra n. 14 at 58, 71; see also J.Ch. Miller, Alexander Hamilton: Portrait in Paradox, Harper, New York 1959, p. 451.

${ }^{66}$ J.Ch. Miller, The Federalist Era 1789-1801, Harper, New York 1960, p. 99, 126. Although the split between Jefferson and Hamilton was caused by the more general conflict of ideas and interests, the process of emergence of the two parties was colored by the foreign policy issue. See D. Malone, Jefferson and the Rights..., supra n. 14 at 445. For reaction of the French Ministers in the United States to the changing attitudes toward France, see the letter of Jean Termant to Minister of Foreign Affairs, dated January $12^{\text {th }}$, 1793. F.J. Turner, Correspondence of the French Ministers to the United States 1791-1797, Da Capo Press, New York 1972, vol. I, p. 166-167.

${ }^{67}$ See C. Read, The Constitution Reconsidered, Columbia University Press, New York 1938, p. 263-264. For the texts of the Constitutions of 1795 and 1799, see J.H. Stewart, Documentary Survey..., supra n. 41 at 571-612, 768-779. 
"After the lapse of a few more years, Napoleon emerged as the supreme power in the land of liberty, equality, and fraternity, and by that time even the most ardent American Jacobin could no longer keep up the pretense that France was merely applying American beliefs in her own distinctively Gallic way". ${ }^{68}$

In conclusion, it has to be admitted that the French Revolution generated a multiplicity of emotions favorable to the search for new foundations of the free government. It focused public attention on the struggle for civil rights and liberties. However, in spite of the enormous emotional involvement of the American public in French politics, the permanent interflow of opinions between both countries and considerable contribution of American political thought to the formation of French constitutional structures, the influence of French revolutionary documents on American constitutional development remained insignificant.

${ }^{68}$ People of Plenty published by A.T. Mason, Free Government..., supra n. 14 at 890 . Howard M. Jones observed that "afterwards, when the British navy closed the seas, and our only source of information about France was London, the prestige of French steadily declined, so that from 1800 to 1815 the teaching of French in the United States fell off." M. Jones, America and French..., supra n. 6 at 216. 